\title{
Sustainable Landscape Management in Tara National Park (Village Jagoštica, Serbia)
}

\author{
Blagojević IvanaA*
}

Received: April 2012 | Revised: June 2012 | Accepted: June 2012

\begin{abstract}
According to the Nature Protection Act of the Republic of Serbia, national park is defined as a large area with natural ecosystems of high value, in terms of conservation, complexity of structures, biogeographical features, cultural-historical values, and flora and fauna wealth. Owing to their exceptional natural integrity, national park is the treasure of great national importance. Villages (hamlets) are integral parts of national park, but are sadly on the verge of disappearing, due to lack of inhabitants. The locals that choose to stay, by fighting for their village's survival and existence, are coming into a conflict with the management board of the national park (mainly directed towards the protection and preservation of biodiversity resources). The research presented here focused on Jagoštica village, located in the far northwestern part of Tara National Park, Serbia. According to the landscape reading, mapped landscape (spatial) elements and social survey, the researched aim was the development of a unique model for sustainable development, focused at protecting diversity of flora and fauna, as well as improving the living standards of local people. Rural tourism and production of local traditional products were found to be the most optimal strategies for moderating the development of this area.
\end{abstract}

Key words: environmental protection, local community, management of natural resources, social benefit, Tara National Park

\section{Introduction}

The increasing variety of areas planned for the protection, combined with the need for their adequate management, has imposed a demand for their classification. According to directives of the IUCN (International Union for Conservation of Nature) 10 categories of protection, divided into three main groups have been established. National park belongs to category II for which the IUCN sub-organizations accept responsibility of monitoring and providing technical advices if required (Cvejić, 2002). The Environment Protection Act of the Republic of Serbia (Sl. glasnik RS, br. 135/04) also defines the categories of protected areas, which are in a correlation to those, outlined under IUCN. Under this act, a national park is in the first category of protection.
A national park is an area comprising of a large number of diverse ecosystems of national importance, the prominent feature of the landscape and a cultural heritage in which man lives in harmony with nature. It is intended to preserve the existing natural values and resources, maintaining the landscape intact, promote geological and biological diversity, as well as meeting the scientific, educational, spiritual, aesthetic, cultural, tourism, health and recreational needs, and support other activities in accordance with the principles of nature conservation and sustainable development (Sl. glasnik RS, 36/2009, 88/2010).

Protected areas hold a special position in terms of the sustainable socio-economic and tourism development of the planet. They could be integrated and contribute to the sustainable development of all spheres

\footnotetext{
A Faculty of Agriculture, University of Novi Sad, Department of fruit science, viticulture, horticulture and landscape architecture, Trg Dositeja Obradovića 8, 21000 Novi Sad

* Corresponding author: ivanab@polj.uns.ac.rs
} 
of socio-economic life of the community (Georgiev, 2010). According to Wells and Brandon (1993), there is a growing recognition that the sustainable management of protected areas ultimately depends on the cooperation and support of the local people. However, benefits derived from the protected areas are the key factor in local population's positive attitude towards conservation. Furthermore, the local population's perception of, and approach to, a protected area is influenced by the benefits they gain from it, as well as the negative consequences of its conservation status (Tomićević, 2006).

For the subject area of this research Jagoštica village has been selected. It is located in the northwestern part of Tara National Park, close to a canyon of Drina River (Figure 1). The village lies in the landscape of outstanding natural values. In demographic terms, it has considerably degraded, and problems in establishing the communication between the management board of the national park and locals are becoming more apparent. Therefore, the study presented in this paper aimed to create a unique model of sustainable management in a mountain village, in accordance with natural laws, thus bringing together economic, natural and social aspects.

\section{Tara National Park as a natural phenomena}

Tara National Park (NP Tara) is located in the far west of Serbia. Bordered by Drina River, it covers the area between cities Višegrad and Bajina Bašta. Administratively the territory of the national park belongs to the municipality Bajina Bašta, with 9 cadastral municipalities among which is village Jagoštica. It covers a total area of $24,989.32$ ha, of which $13,587.04$ ha is state-owned, 10,559.71 ha is owned privately and 842.57 ha is in the possession of the Serbian Orthodox Church (Nacrt zakona o Nacionalnom parku "Tara", 2012). The average altitude is about $1150 \mathrm{~m}$ (Tomićević, 2005).

Various geomorphologic forms are established in NP Tara, some of which have been widely represented, such as caves, bays, sinkholes, combs, canyons and gorges. NP Tara is characterized by many attractive topographical forms, among which canyons and gorges, stand out for their uniqueness and beauty. The area of NP Tara has great diversity of lithological compositions, which is a proof of its long and tumultuous geological history. There are igneous, metamorphic and sedimentary rocks, that started forming in the Paleozoic period (Grupa autora, 2002). The same authors point out that the mountain Tara, due to the limestone composition of its surface, does not retain rainwater, and it is relatively poor in promoting surface flows. Consequently, its waterflows are comprised from the fast mountain rivers, streams, springs and

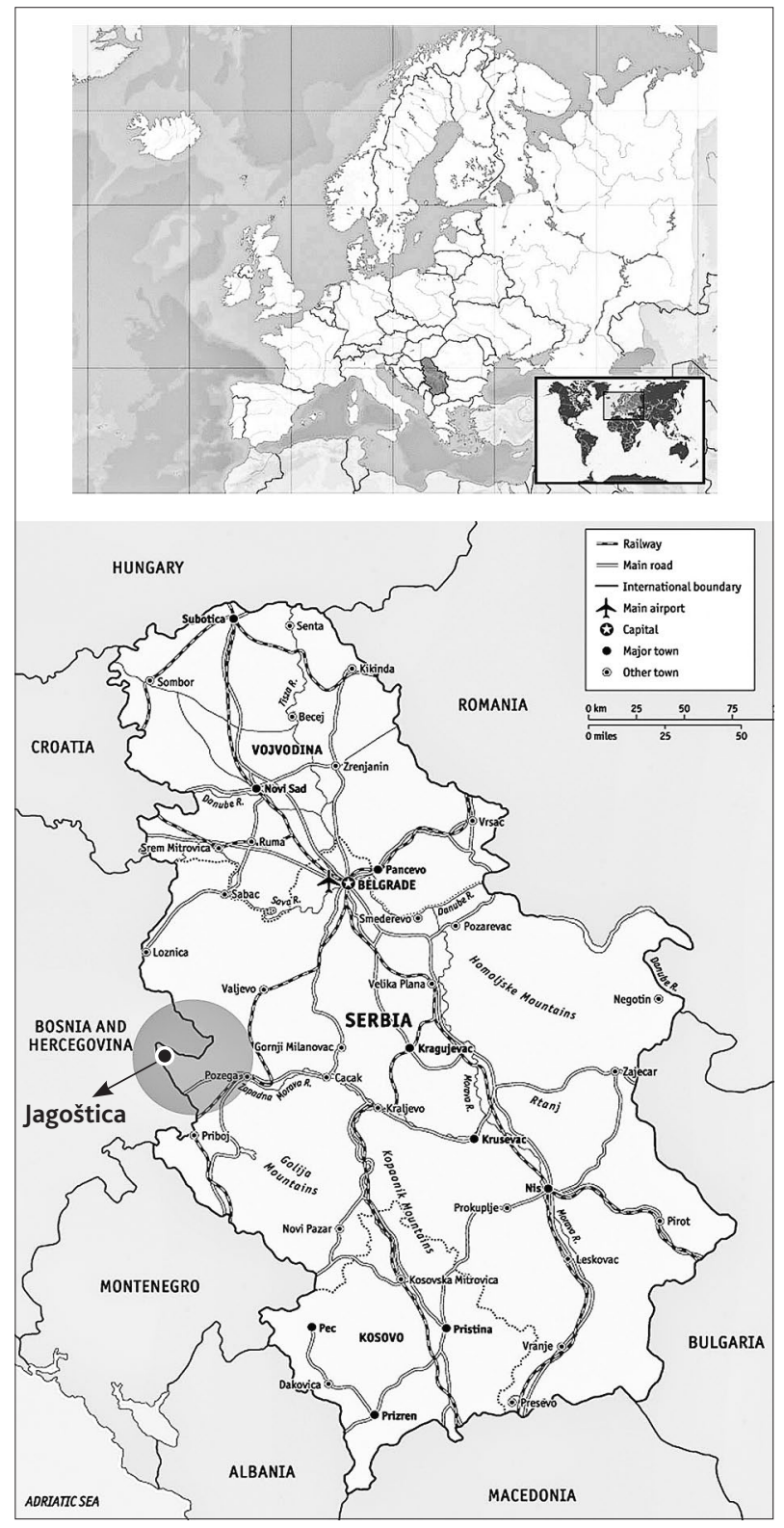

Figure 1. Location of the village Jagoštica (NP Tara, Serbia) (source: http://www.inmold-ltd.com/en/location.php; readjusted by Ivana Blagojević)

wells. Almost all the mountain streams belong to Drina River basin, with exception of a few located in the basin of the river Đetinja (Grupa autora, 2002).

Mountain Tara has a temperate-continental climate. Above the mountain, warm airflows from the south and cold airflows from the north coincide. Thus, specific microclimate conditions prevail, whereby the high humidity promotes relative stability of climatic factors, facilitating the survival of sensitive and rare species on the mountain (Gajić, 1989).

As Gajić (1989) points out, NP Tara is typical forest area dominated by beech species, fir and spruce (Piceo-Abieti-Fagetum). Although some forest communities of ash and hornbeam (Fraxinus ornus L., Ostrya carpinifolia Scop.), oak and pine (Quercus conferta 
Ten., Quercus cerris L., Quercus petraea (Mattuschka) Liebl., J.F.Arnold) can also be found, broadleaf-conifer and conifer forests cover the most of the park area. Broadleaf-conifer forests, spruce in particular, are the natural value by which the mountain Tara is recognized throughout the world. The spruce forests are usually located at barely accessible and steep rocky limestone and serpentine. Specifically, there is an interesting and unique rare forest community of Pančić spruce (Picea omorika (Pančić) Purk.). The same author points out that meadow plant community covers large areas. Although these habitats are mainly secondary formations, they are very important, because under these kinds of communities, rare and endangered plant species proliferate. The vegetation of the mountain Tara is also of interest due to the presence of numerous small peat swamps and peat meadows.

In the scope of NP Tara, several settlements still remain, namely villages Jagoštica and Rastište, Jasikovica hamlet (village Solotuša) and Čokić hamlet (village Rača). These villages are of scattered hilly-mountain type, established on the cleared land between woods. They are spread throughout the territory of the park, at elevations ranging from 410 to $1000 \mathrm{~m}$ above the sea level. The areas of the villages of Jagoštica and Rastište are entirely within the national park perimeters. Spatially very dispersed village Rastište has 471 residents and presents the largest and most widespread village in the park. Jagoštica village, with only 152 inhabitants, is located on the mountain Zvezda, and spans elevations from 800 to $1000 \mathrm{~m}$ above the sea level. It is surrounded on three sides by natural reserves, and is bounded by the Drina canyon to the north and the west (Javno preduzeće "Nacionalni park Tara", 2002).

\section{Management in the Tara National Park}

Management of the natural values in Serbia is regulated by the Environment Protection Act of the Republic of Serbia ("Sl. glasnik RS", br. 88/10), whilst management of national parks is entrusted to the public enterprises (Tomićević, 2005). Tomićević (2005) emphasized that protection of natural resources comprises by defining the specific regime of utilization, protection of biodiversity (conservation of genetic, species and ecosystem biodiversity) and hazardous factors, as well as undertaking adequate measures for its conservation. The same author highlighted that aims and tasks of public enterprises include protection, conservation and improvement of biogeographical characteristics of the area, ecosystems and wildlife diversity, and prevention from degradation; scientific and research activities; cultural and educational activities; as well as control of the implementation of protection regimes in the Park.

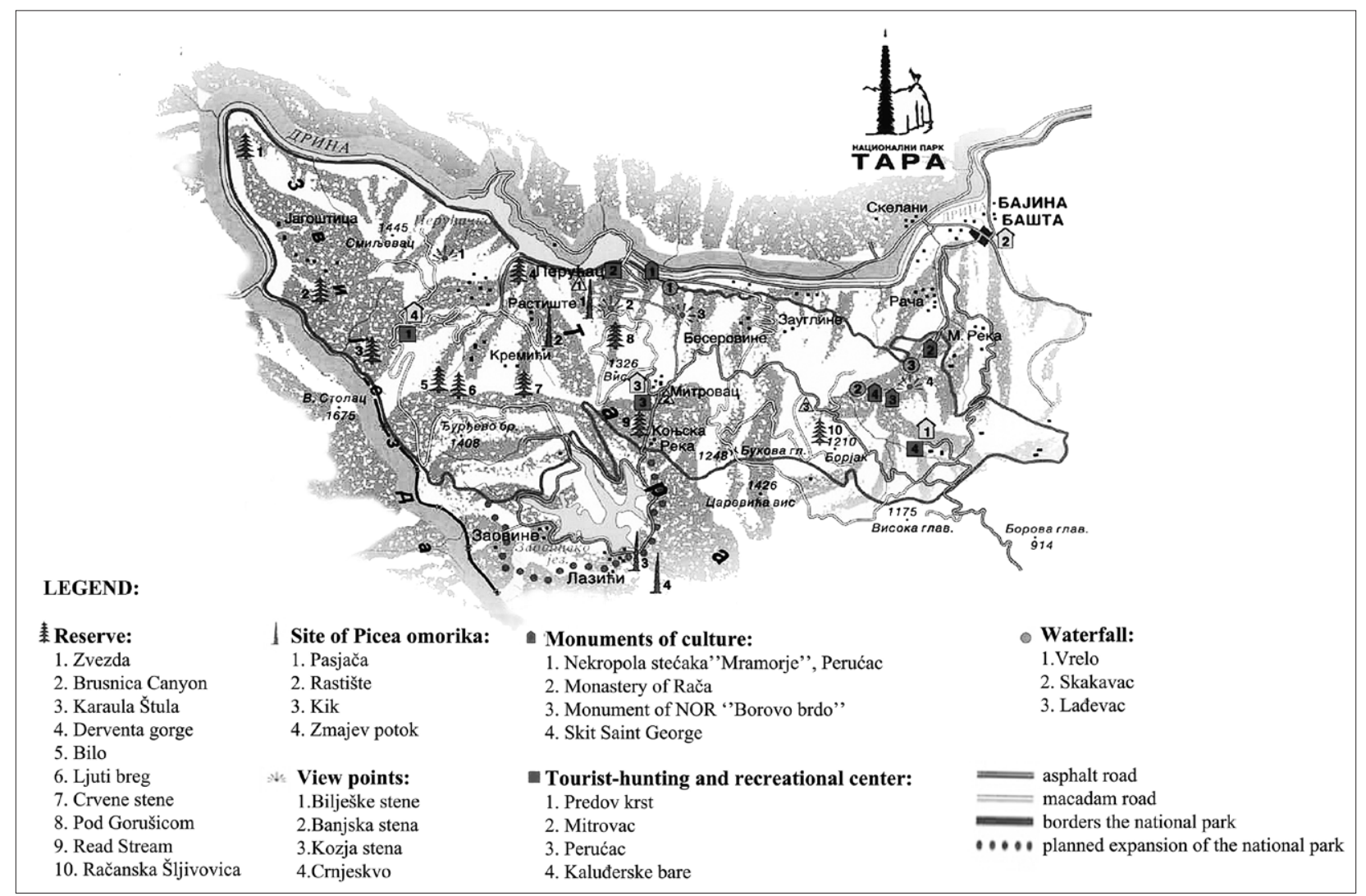

Figure 2. Map of NP Tara with location of natural reserves among three determined regimes of protection (source: $h$ ttp://www.tara-planina.com/tara.html; readjusted by Ivana Blagojević) 
Funds for protection and development of the national parks and other protected resources, defined by the Environment Protection Act, are provided from the state budget, the income originating from activities performed by enterprises or other relevant organizations in charge of managing the protected natural value, as well as the compensation for utilization of the protected natural value, and other sources in agreement with the law (Cvejić, 1999).

Three regimes of protection are established in the NP Tara area (Figure 2). The first regime covers $3,134.47$ ha or $12.54 \%$ of the area of NP Tara, and includes the following natural reserves: Brusnica Canyon, Zvezda, Derventa gorge, Rača gorge, Račanska Šljivovica, Red stream, Pod Gorušicom, Crvene stene, Bilo, Ljuti breg, Zmajevac stream, Vranjak, Studenac and Sklopovi canyon. The second regime of protection covers total area of $6,981.37$ ha or $27.94 \%$ of the area of NP Tara and it includes the following landscape units: Jagoštica, Derventa gorge and Drina canyon, landscape areas of Rača, Račanska Šljivovica II, Jarevac, Red stream II, Pod Gorušicom II, Crni vrh, Ostenjak Ravna stena - Tetrebica, Janjač and Popovića. The third regime of protection covers $14,873.47$ ha, or $59.50 \%$ of the area of NP Tara. It covers the remaining part of the national park, excluded from the first and second regime of protection (Nacrt zakona o Nacionalnom parku "Tara", 2012).

\section{Methods and data}

For the purpose of this research, several data collection methods and approaches have been used. The methodology has been developed and implemented in three phases: characterization, evaluation and developing ideas.

The characterization phase included identification of the researched area through landscape reading and description of specific relations between man and nature (studio work-report reviews, statistical data and interviews with local people). Interviews were conducted in a social survey format, covering eight randomly sampled households, using a previously prepared questionnaire. The interviews consisted of open-ended questions aimed at clarifying: who are the actors involved, what power and resources they have and identifying informal rules concerning conflicts. The interviews were carried out face-to-face. Of
12 interviewed individuals, 5 were female and 7 were male. Their ages were mostly in the 61 to 90 range (four interviewees were between ages 30 and 60).

According to set goals (management and nature, socio-economic benefit) the phase of evaluation was based on data obtained in the characterization phase. The results of the evaluation were intended for use in making decisions regarding the future strategy of landscape development and management. The collected data were subjected to SWOT analysis, a qualitative analytical method used to estimate strengths, weaknesses, opportunities and threats. The analysis enabled isolation of rural values, their shortcomings, opportunities for further development, as well as the threats that endanger further village development. Strengths and weaknesses are internal factors while opportunities and threats are external.

The phase of developing ideas has emerged as the outcome of the previous two phases.

\section{Results}

As noted in the methodology section, this research was conducted in three phases (Table 1). Each phase consisted of numerous steps, necessary for the further progress. The steps are determined in accordance to the objectives of the research.

\section{The characterization phase}

Based on the categorization of the form that they occupy in the space and on the function that they have in the same, the spatial elements are divided into the following categories: areas, lines, and points. The interaction of form and function, is based on the content, within the area, not directly related to the surface area that category occupies in the space. In order to that, management of the spatial elements, categorized in this way, is much easier.

Areas are objects that are defined by boundary lines, location and content of the elements of biotic and abiotic nature and may include lines and points. They could comprise of the following categories: pastures, extensive pastures, meadows, wet meager meadows, fat meadow fields and gardens, forest, spinney, small wetlands, coppice forests, gardens and plume orchards.

Lines represent the objects that are defined by their length, location, spatial orientation and the content of

Table 1. Research phases and steps within each phase

\begin{tabular}{|c|c|c|c|c|c|c|}
\hline \multicolumn{4}{|c|}{ The phase of characterization } & $\begin{array}{c}\text { The phase of } \\
\text { evaluation }\end{array}$ & \multicolumn{2}{c|}{ The phase of developing ideas } \\
\hline $\begin{array}{c}\text { Lanscape } \\
\text { reading }\end{array}$ & Social survey & $\begin{array}{c}\text { Relation between } \\
\text { man and nature }\end{array}$ & SWOT analysis & Local scenario & Trend scenario & Expert scenario \\
\hline
\end{tabular}


Table 2. Assigned spatial elements of the village Jagoštica within the emphasized category according to local's personal perception

\begin{tabular}{|c|c|c|c|c|c|c|c|c|}
\hline \multicolumn{3}{|c|}{ Area } & \multicolumn{4}{c|}{ Linear } & \multicolumn{3}{c|}{ Punctual } \\
\hline & Past & Now & & Past & Now & & Past & Now \\
\hline pasture & +++ & + & paths & +++ & ++ & cemetery & +++ & + \\
\hline meadow & +++ & ++ & hollow paths & $\begin{array}{c}/ / \text { were } \\
\text { cattle } \\
\text { paths }\end{array}$ & +++ & springs & +++ & +++ \\
\hline forests & ++ & +++ & macadam & $\begin{array}{c}/ \text { (no } \\
\text { exist) }\end{array}$ & +++ & church & +++ & + \\
\hline hunting area & +++ & + & field roads & +++ & ++ & school & +++ & + \\
\hline spinney & +++ & + & creeks & +++ & + & water mills & +++ & $\begin{array}{c}\text { (no in } \\
\text { use) }\end{array}$ \\
\hline orchard & +++ & ++ & channels (ditches) & +++ & ++ & houses & +++ & + \\
\hline
\end{tabular}

* high+++; medium ++; low +

biotic elements and may contain points. Linear elements established in the researched area are: network of paths, hollow paths, ditches, creeks, fences, electric and metal fences, Salix sp. plantations, and macadam roads.

Points represent objects in space which are part of the areas or lines. Alternatively, they could be separate objects with defined position in the space, with qualitative and quantitative atributes. Points established in the researched area are: graves, wells, houses (ruins of), stables and storages, hay storages, solitaires, Tilia sp., water mills and a church.

By analyzing the spatial area of village Jagoštica (Table 2) it was found evidence of significant degradation over time, in terms of population and loss of certain spatial elements. According to the last census, conducted in 2002, there were 53 households and 163 inhabitants in Jagoštica village (Republički zavod za statistiku, 2004), supporting the evidence of emigration over the last 50 years (1947, Jagoštica had 441 inhabitants). In 2006, in the village school (closed in 2008) there were six pupils, and only three in 2007, compared to 73 in 1947 (Tomićević, 2005).

Sociological survey (Table 3 ) identified agriculture and forestry as the main occupation of the inhabitants. A small number of inhabitants are employed, mainly in forestry. The employment opportunities in other sectors are limited, leading to a population drain, which, along with low birth rate, leads to the decline in the population. Due to inadequate living conditions, most inhabitants opt to emigrate from the village. The reasons for leaving are numerous, including: lack of education, unemployment, inadequate infrastructure (water system, electricity, roads, and telecommunication), no markets for products, no medical care, overpopulation as well as lack of arable land, meadows and pastures.
Respondents confirmed that communication between public enterprises of NP Tara and locals is at a very low level. There are numerous restrictions and widespread corruption. On the other hand, the public enterprises of the park confirm that wild lumbering by local people is very frequent. Undeveloped administration in the village could be one of the reasons for this poor communication. There are no local managers that can represent locals and act as intermediaries between public enterprises of NP Tara and local communities. Uncontrolled lumbering, often negated by survey respondents, is one of the major problems of the village and its nature, yet it is the major source of income for the households. On the other hand, unsustainable management of the national park could lead to increasing the number of predators (wolves and bears) on arable land, which directly affects the local people, creating further problems.

When asked if they wanted to return and stay in the village, local youth responded that they would stay in the village with their families, if they had a permanent source of income. In addition, as a major shortcoming affecting the village, respondents emphasized a poor infrastructure and difficult communication with Bajina Bašta. The interviews revealed strong will of the inhabitants for the village to progress and prosper, but also identified areas that are outside their control that must be changed. For example, it is necessary to rebuild the roads in order to achieve good communication with other hamlets and Bajina Bašta. Moreover, in order to achieve sustainable living in the entire NP Tara region, children could be educated together in one common school, whereas all inhabitants could be treated in one common health clinic, at a location equidistant from all existing hamlets. 


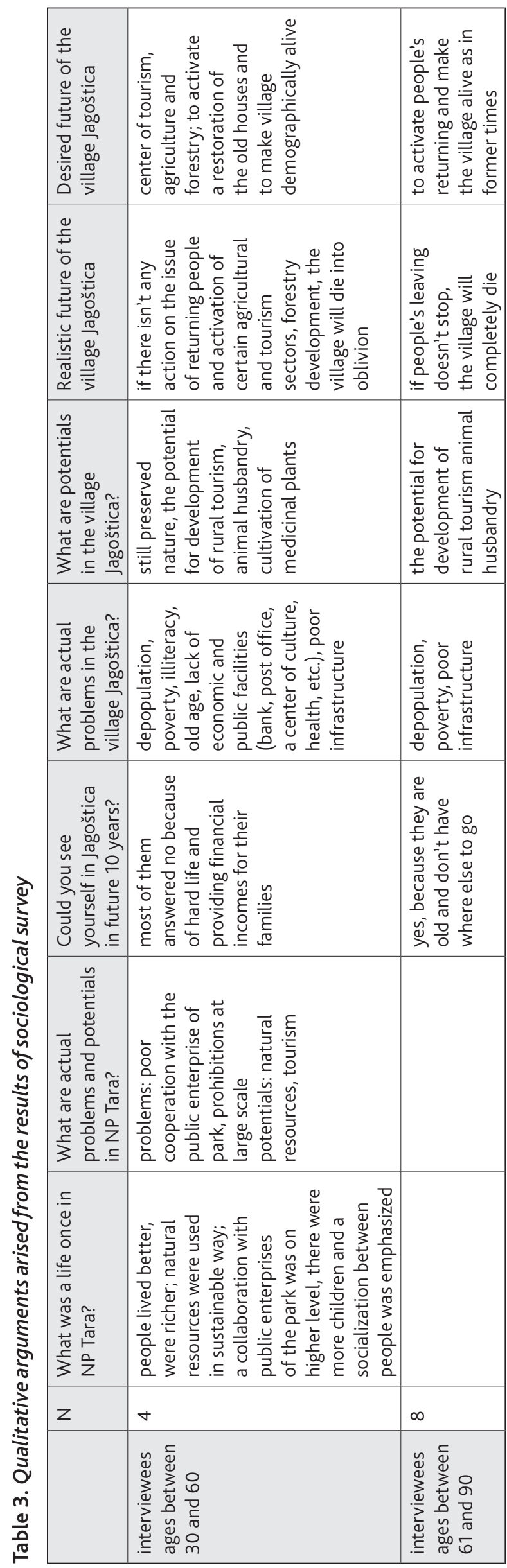

\section{The phase of evaluation}

As noted earlier, the evaluation of the researched area was performed by conducting SWOT analysis (Table 4). The outline for the implementation of the SWOT analysis included the following categories: people, demography, land use, landscape and landscape elements and products. Natural values and geographical position were identified as the key strengths of the region. Opportunities for the village are also numerous and include: organic agricultural production, good market/cluster foundations, rural tourism and so on. On the other hand, numerous weaknesses have also been identified, the key ones being aging population, inferior infrastructure, decrease of arable land area, low educational level- lack of ecological awareness amongs locals, and inadequate communication with public enterprises of the national park. Finally, emigration is increasing and village income is on the decline.

\section{The developing ideas phase}

Developing ideas, which was the last stage of the research process, was based on the creation of three scenarios-trend, local and expert.

The first scenario, Trend scenario, focuses on the outcome of no further steps being taken in the process of area development and improvement. The research showed that the number of the abandoned households would increase, tradition and customs would no longer be practiced, so the village would cease to exist. More isolated hamlets would yield more abandoned land, which will result in creation a mosaics of different types and stages (trees and shrubs) in the landscape. There would be a natural succession, biodiversity would be changed, whereby one species would be replaced by another, successfully adapted to the new (changed) environmental conditions. Natural wetland forests would be replaced by wet meager meadows. The Park would partially lose its value, as the invasive species would predominate. However, due to the succession, some new, rare and innovative plant and animal species would appear, for which the area would be recognized in the biological world, and a number of wild animals would also increase.

The second scenario, Local scenario, is based on the visions of inhabitants and their plans for village Jagoštica, who see its future as a center for animal husbandry and rural tourism (agro-tourism, eco tourism). As such, it will bring better infrastructure and communication, both to the surrounding hamlets, and Serbia as a whole. Some respondents even see the future of Jagoštica in exploitation of natural water resources (springs) for the construction of the mineral water factory. For those villagers, the natural resources were not that relevant and the focus was on the eco- 
Table 4. Elements of the SWOT analysis for the village Jagoštica, NP Tara

\begin{tabular}{|l|l|}
\hline Strengths & Weakness \\
\hline - Landscape & - Isolation \\
- Position in National Park (I and II zone) & - Old people \\
- Rare Species & - Bad infrastructure \\
- Good quality of water, air & - Low education \\
- Forest (timber, non timber forest products) & - No administration system in village \\
- Traditional Style of Life & - Predators \\
- Wilderness & - Pessimism and disappointment of people \\
- Near border to the Republic Srpska & - Bad relationship with National Park \\
- Biodiversity & - Hard life during winter \\
- Gorge of the river Drina & - No medical care \\
- Hunting area & - Slow information flow from Serbia \\
- Church and school & - No market for products \\
& - No engagement of local people \\
\hline Opportunities & Threatens \\
\hline - Organic agricultural production & - Depopulation of people \\
- Cooperation with the Republic Srpska & - Lack of money \\
- Organized market for all kind of products & \\
- Alternative energies & \\
- Rural tourism & \\
- Credits from National Parks or others & \\
- Hunting tourism & \\
- Photo safari \& bird watching & \\
- Possible interests from foreign investors & \\
- Arising awareness of people and education & \\
- Good marketing & \\
\hline
\end{tabular}

nomic value and prosperity of the village. Development and raising commercial and industrial property, in the opinion of the locals, will return people to the village. Exploitation of the natural resources, according to the respondents, will also help in developing rural tourism.

The third scenario, Expert scenario, is a combination of the two previous scenarios, which are aligned with nature, national park and its surroundings, yet based on satisfying the principles of sustainable development-ecological, economic and social. It represents the only possible sustainable scenario.

In order to open possibilities for the implementation of Expert scenario, basic requirements should be primarily directed towards improving the infrastructure (rearrangement of macadam road, improving asphalt, development of telephone and television infrastructure networks, etc.). Although the Park area has great potential for rural tourism, the initiative must come from outside. First, throughout the various projects of spatial planning, the accent must be placed at the education of the local people, as well as in the field of rural tourism, combined with efforts of raising environmental awareness and in cooperation with the public enterprises of NP Tara. In the process of development of rural tourism, local brands that are typical for the village Jagoštica should be emphasized. Development of hunting tourism would be also very impor- tant, and certainly good marketing is the foundation of all the potential initiatives.

Establishment of clusters, namely agricultural (bee farming, mushroom cultivation, production of spices and medicinal herbs, plum production, etc.) and forestry cooperative farms could bring great benefits to the area. In the beginning, financial support and mechanization will be needed, whereas in the future, the area should become self-sufficient. Clusters, as geographically concentrated groups of interconnected and institutions of specific activity, can contribute significantly to the development of organic farming. Some of the objectives of association under cluster concept are: achievement of greater competitiveness and better product placement, expansion and establishing position in the international markets, more affective usage of natural and other resources, establishing closer links and cooperation between businesses, training and education, facilitating the process of introducing innovation and new technologies (Glavaš Trbić et al., 2011).

With the help of farm cooperatives, the village would have easier access to markets, financing and so on. One of the objectives could be creating products with Tara-label. As a result, a single integrated system would soon emerge, meeting the village needs. On one hand, the environmental categories would be satisfied by nature conservation, whilst on the other, 
economic and sociological categories will be meet too, by highlighting the value of local community and its traditional products. A model of soft land use system would be created, in order to preserve a cultural landscape, e.g. through significant pasture improvements, and extensive animal husbandry. Finally, an extensive agriculture directive will create new aspects of a cultural landscape, which could be a brand of the NP Tara, village Jagoštica.

\section{Discussion}

National park is area that covers large spaces of great beauty, with ecosystems that are not changed by human use and where flora and fauna, geological and morphological features have a particular importance for science, education and recreation. Consequently, national park is placed under special protection regime. However, people are integral part of any national park. They live there, whether they reside on the park's edge or within its perimeters. Very often there is a conflict of these two subjects (management board of the national park and locals). The conflicts appear primary because the nature protection is great competitor to interests focusing solely on production, but are also a result of establishment large areas for the protection, whereby the prohibition regimes for the locals increase.

According to the IUCN categories, NP Tara has degree II protection status and as such requires either strict control or a liberal regime (depending on the sensitivity of ecosystems) in the areas of hunting, natural resource usage and tourism activities (Cvejić, 2002). From aforementioned, in order to develop effective nature protection strategy, that allows for sustainable development of the villages, as an integral part of the park, a joint collaboration between local residents and public enterprises of the park is essential.

The case of village Jagoštica, situated within the NP Tara is not present only in Serbia but many other countries facing with similar problems. A similar example is the conservation of the Bialowieza Primeval Forest in Poland, where between 1918 and 2010. the role of local authorities changed from no influence to limited control over decision making regarding designation and enlargement of Bialowieza National Park (BNP). As a result of these changes, attempts to enlarge BNP over the entire forest were undermined. The evidence shows that power relations and instrumental reasons constituted the main drivers of the changing participation pattern, while deliberative rationale was clearly lacking. As a result, conservation goals were only partially achieved (Mitchell, Parkins, 2011).

According to the new conservation paradigm, protected areas should contribute to the socio-economic development of host communities and the latter ought to be included in participatory decision-making concerning the researched area. Historically, in such cases, host communities were typically not involved in decision-making pertaining to protected areas and were often prohibited from using their territories. This led to negative attitudes in local communities toward protected areas, which hindered their establishment and enlargement (Niedzialkowski, et al., 2012).

The management of nature and the changing relationships between local communities and the public enterprises managing natural resources are affected by a number of factors, including climatological, geographical and political, as is evident in many countries. In Central, Eastern and South-Eastern Europe, as Čoček (2010) emphasized, post-communist transformation has been progressing at varying intensity with varying rates of success. Of the countries involved, Serbia was the last to begin the transformation process and it has done so under difficult political and economic circumstances. As one of the post-communist countries, Czech Republic had a similar problem to that Serbia is facing with the village Jagoštica. However, primary geographical factors of regional development have been identified, which could be considered applicable for the most other post-communist countries. For example: (1) The hierarchical position of a region (its centre) in its national settlement system hierarchy, with special emphasis placed on the duality between metropolitan and non-metropolitan regions. (2) The macro-geographical position of an area, in terms of its distance from developed centers. This is derived, first, from the distance from the national capital and, second, from foreign centers of development. (3) The third factor is inherited economic specialization. Nevertheless, certain factors must be interpreted with caution, and the regional specifics of Serbia must be considered. (Čoček, 2010).

According to the European Environment Agency, environmental quality is a general term for properties and characteristics of an environment, either generalized or local, as they affect the human beings and other organisms (Surd et al., 2011).

\section{Conclusion}

At present we are facing the loss of many natural ecosystems, due to a variety of global changes, as phenomena that cannot always be foreseen and very often cannot be influenced at a local level. However, preservation, protection and improvement of natural habitats, such as national parks can be locally observed. Therefore, conflicts between local communities and public enterprises managing national parks should be addressed and potential solutions must satisfy both 
sides. A valid quality of life assessment must be related to the values of diversity and the interests of a local community.

In contrast to the traditional paradigm in which protected areas were managed by central government without external input, the new paradigm emphasizes cooperation among the central government, regional and local authorities and indigenous communities.

Increasing participation in terms of power does not necessarily lead to improvements in biodiversity conservation. There are examples where a longterm participatory process, including shift of power to lower levels and attention to the quality of the process, brought about consensus, leading to establishment of protected areas. Other accounts indicate that such measures were used in wrong contexts or were conducted in a half-hearted way that led to even more conflicts. In order to address this problem, a multidisciplinary approach must be adopted, with the aim to incorporate multiple scenarios based on different criteria that would be the result of integration of the visions of both entities with vested interest in the protected areas. This way, biodiversity conservation will be balanced, economic goals of the local communities will be satisfied and political and nature protection goals of the national park will be achieved.

\section{References}

Cvejić, J. 1999. Planiranje i uređivanje predela - zaštita prirode. Šumarski fakultet, Univerzitet u Beogradu, Beograd, 203 pp. (in Serbian)

Cvejić, J. 2002. Zaštita životne sredine. Šumarski fakultet, Univerzitet u Beogradu, Beograd, 67 pp. (in Serbian)

Čoček, L. 2010. Patterns of Regional Development in Serbia: A Multivariate Statistical Analysis, Geographica Pannonica 14, 1, 14-22.

Gajić, M. 1989. Flora Nacionalnog parka Tara. Šumarski fakultet, Beograd, 146. pp. (in Serbian)

Georgiev, L. G. 2010. The System of protected areas in Bulgaria in terms of the implementation of the concepts of sustainable and alternative tourism. Geographica Pannonica14, 3, 83-91.

Glavaš-Trbić, D., Maksimović, G., Pejanović, R. 2011. The importance and role of clusters in organic food production. 22nd International symposium "Food safety production", Trebinje, Bosnia and Herzegovina, 19 - 25 June, 2011, 175-177.
Zavod za zaštitu prirode Srbije 2002. Rezervat biosfere Tara. Beograd, 120 pp.

Mitchell, R., Parkins, J. 2011. The Challenge of Developing Social Indicators for Cumulative Effects Assessment and Land Use Planning. Ecology and Society 16, 2, 29, Poland.

Nacrt zakona o Nacionalnom parku “Tara”, preuzeto sa sajta Ministarstva životne sredine, rudarstva i prostornog planiranja, januar 2012. godine, http://www. ekoplan.gov.rs/src/1-3-Nacrti-289-document.htm.

Niedzialkowski, K., Paavola, J., Jedrzejewska, B. 2012. Participation and Protected Area Governance: the Impact of Changing Influence of Local Authorities on the Conservation of the Bialowieza Primeval Forest, Poland. Ecology and Society 17, 1, 2, Poland.

Javno preduzeće "Nacionalni park Tara" 2002. Program razvoja i zaštite područja Nacionalnog parka Tara za 2003. godinu, Bajina Bašta, 2-8.

Republički zavod za statistiku 2004. Popis stanovništva, domaćinstava i stanova u 2002. godini, Stanovništvo, Uporedni pregled broja stanovnika po popisima 1941-2002. Podaci po naseljima, 10, Republika Srbija, Republički zavod za statistiku, Beograd.

Surd V., Alexe R., Kantor C.M., Tanislav D., Sencovici M. 2011. The Evaluation of the Environmental Quality in Romania. Geographica Pannonica 15, 2, 42-50.

Tomićević, J. 2005. Towards Participatory Management: Linking People, Resources and Managemant, A Socio-Economic Study of Tara national Park, doctoral theses. Schriftenreihe des Instituts für Landespflege der Albert-Ludwigs-Universität Freiburg, 187 pp. (in English)

Tomićević, J. 2006. The impact of benefits on conservation attitudes of local people in Tara National Park. Scientific conference: „Management of forest ecosystems in national parks and other protected areas", Proceedings, Jahorina - NP Sutjeska, 05. o8. July 2006., 485-492.

Wells, M. P., Brandon, K. B. 1993. The principle and practice of buffer zones and local participation in biodiversity conservation. Ambio 22, 2, 157-162.

Zakon o zaštiti prirode Republike Srbije. "Službeni glasnik RS”, br. 36/2009 i 88/2010.

Zakon o zaštiti životne sredine Republike Srbije. “Službeni glasnik RS", br. 135/o4.

Zakon o Prostornom planu Republike Srbije od 2010. do 2020. "Službeni glasnik RS”, br. 88/10. 